\title{
A Literature Review on Design of Mini Rice Milling Machine Atif Jamal
}

\author{
M.Tech Scholar, Department of Mechanical Engineering Design, Anjuman College of Engineering and
} Technology, Sadar, Nagpur, Maharashtra, India

\begin{abstract}
Article Info

Volume 8, Issue 4

Page Number : 01-04

Publication Issue

July-August-2021

Article History

Accepted : 25 June 2021

Published : 02 July 2021

Rice mill is important step in post production of rice, past studies had proven that supply of rice can be increased by additional conversion of paddy to rice through use of modern paddy processing techniques. Aim of this project will be to provide an alternative solution to farmers in form of a portable rice mill machine and decrease dependency on rice mill industries and own a feasible solution for rice milling and own the byproduct obtained from milling process such as bran and husk. A pair to leather roller will be used to remove the husk and mini huller mill will be used for whitening of rice. In this study, we will use conventional method as well as CAD model for designing a portable rice mill machine. Then analysis of design will be performed comparing to study and existing models. After final analysis, when result is found to be safe, design will be finalized.
\end{abstract}

Keywords : Milling, Whitening Chamber, Roller Chamber

\section{INTRODUCTION}

India is the second biggest rice producing country in the world after China. It contributes about 20 percent of the world output of rice. Paddy being the major cereal crop of India covers an area of more than 42.8 million hectares, the largest under any single crop (FAO, 1995). It has been stated by the Department of Agriculture, Government of India that in 1985-86 production of paddy was of the order of 96 million tones which was increased to 115 million tons in 1995-96 and is expected to increase to 130 million tons by year 2000. It is grown in almost all the provinces of the country but more than 86 percent of the total production accounts for the States of Andhra
Pradesh, West Bengal, Tamil Nadu, Uttar Pradesh, Bihar, Orissa, Madhya Pradesh, Punjab and Assam. Rice production, processing and marketing constitute the biggest industry in the country. Indian rice milling industry is the oldest and largest agro-based industry. The annual production of paddy was estimated at over 521 million tones, mostly in developing countries and the amount is rising at an average rate of 3 percent per annum (FAO, 1995). It was, however, the serious food crisis in the early sixties which highlighted the need for a proper policy towards the industry. This led to joint study of the industry by the Government of India and the Ford Foundation of India. The study pointed out that the overall supply of rice could be augmented 
substantially with additional yield obtained through modernization of the existing rice processing techniques. A number of studies were also undertaken and came out with the same findings. For cleaning the paddy farmer has to transport paddy to the private rice mill in their area. Rice mill is important step in post production of rice, past studies had proven that supply of rice can be increased by additional conversion of paddy to rice through use of modern paddy processing techniques.

Thus objective of our project is to design machine that will use effective techniques for

(a) Husk removing of paddy

(b) Machine drying/ parboiling of paddy (to add strength)

(c) Milling and polishing

(d) Storing and packing

\section{Problem Statement}

Indian rice mills are the oldest agro based industries. The paddy cleaning process in a private rice mill is some time a long and costly process for farmers as they have to wait for their turn which some time lead to exploitation of the farmers. Existing huller mills have $60-68 \%$ recovery of rice from paddy and $10-25 \%$ loss where as modern mill have $68-72 \%$ recovery and $5-7 \%$ loss. $10 \%$ of paddy/rice is loss in transport, storage and processing. Hence advance and handy portable rice mill will reduce the loss.

\section{Research Methodology}

In present study, we will study the different model and research on mini rice mill and accumulate data required to design a effective steps for rice milling in a small machine then a CAD model will be generated considering the requirements and which will complain according to our milling process. Design will be analyzed according to study and feasible design will be finalized.

\section{A. Data Accumulation}

\section{Requirements}

- $\quad$ Matched Power $3 \mathrm{HP}(2.2-3 \mathrm{kw}) 1.5-2.2 \mathrm{kw}$

- Operation manual feeding and motor drive manual feeding and motor drive

- Material Metallic steel (MS) Metallic steel (MS)

- Weight Approx $65 \mathrm{~kg}$ with motor

- Power source $3 \mathrm{HP}$ single phase electric motor Voltage $220 \pm 10 \mathrm{~V}$ Frequency $50 \mathrm{~Hz}$ Overall dimensions (mm) 1250×530×1125 Rotor speed (r/min) 1400-1600 5500 Rotor diameter (mm) 40 210

- $\quad$ Rice sieve (mm) Size 166 *72 Thickness: 1.2

\section{B. Problems}

After studying the components of the rice milling machine and parameters related to rice milling, the causes of high rice breakage percentage were found to be as follows.

- $\quad$ Machine - Knob spacing adjustment, inadequate maintenance.

- Method - Paddy rice flow rate, motor revolution speed.

- People -Inadequate knowledge and skills on machine usage.

- Raw Materials - Paddy rice moisture, rice strain, paddy rice storage.

\section{CAD Modeling of Mini Rice Milling Machine}




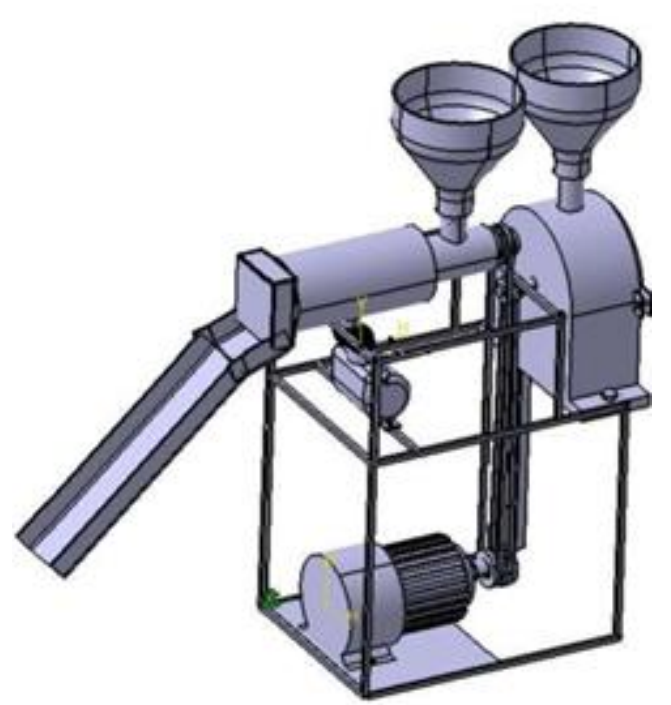

Figure1: 3D CAD model of mini rice milling machine

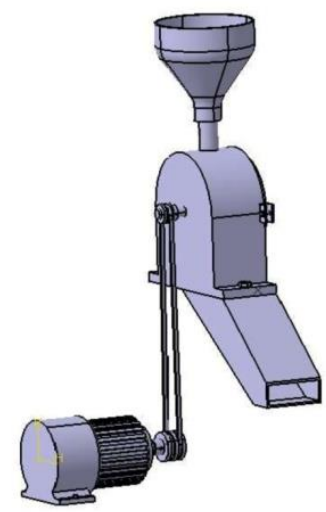

Figure2: Lather roller housing

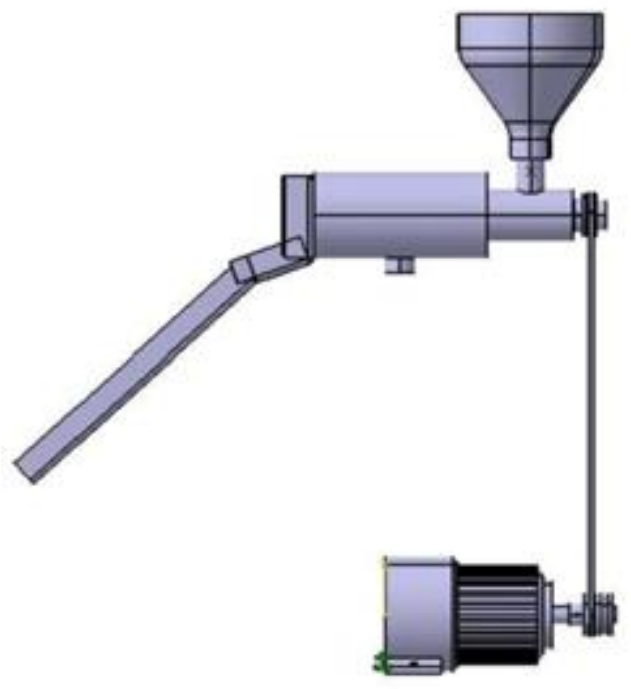

Figure3: Rice whitening chamber

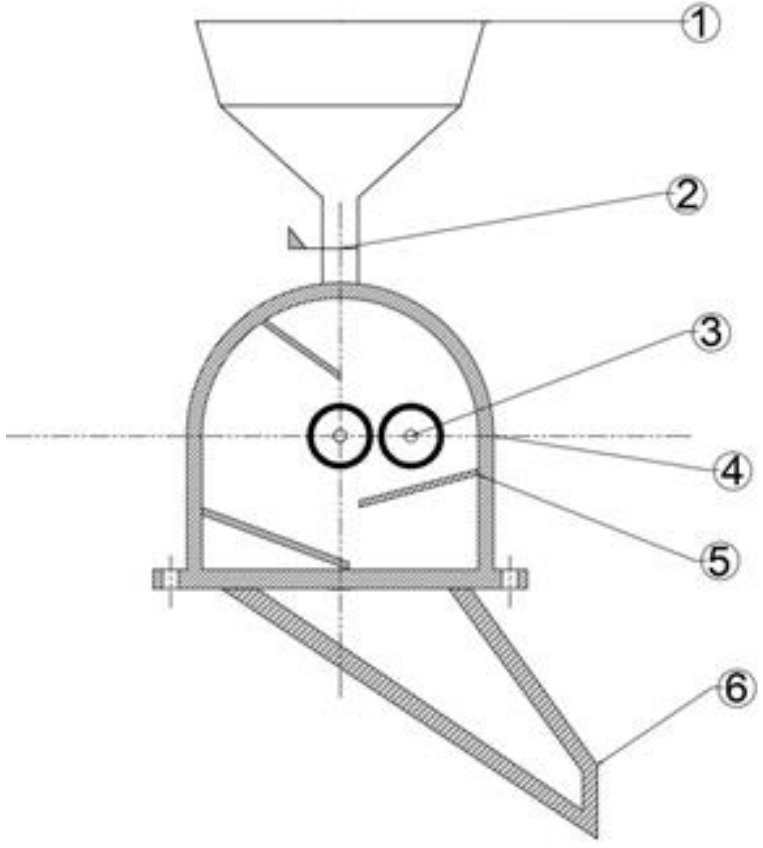

Figure 4: 2D cut section of roller chamber

TABLE 1

LABELING FOR FIGURE 4

\begin{tabular}{|l|l|}
\hline $\begin{array}{l}\text { Sr } \\
\text { No }\end{array}$ & Components Name \\
\hline 1. & Hopper \\
\hline 2. & Feed adjuster plate \\
\hline 3. & Leather roller \\
\hline 4. & Roller chamber \\
\hline 5. & Direction plate \\
\hline 6. & Rice discharge tray \\
\hline
\end{tabular}

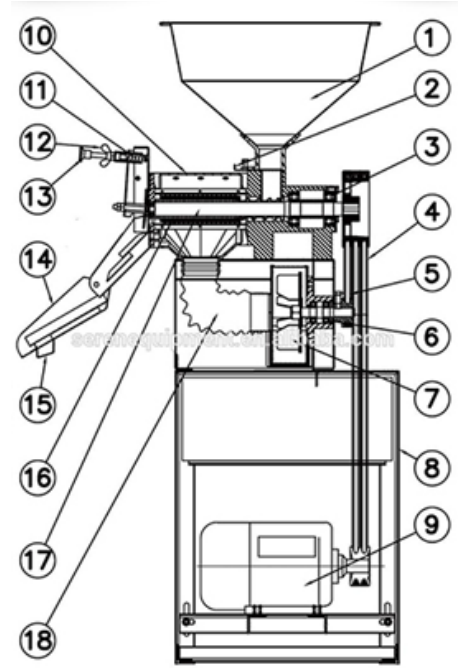

Figure 5: 2D cut section of whitening chamber 


\section{REFERENCES}

TABLE 2

LABELING FOR FIGURE 5

\begin{tabular}{|l|l|}
\hline Sr.no & Component Name \\
\hline 1. & hopper \\
\hline 2. & Feed adjuster \\
\hline 3. & bearing \\
\hline 4. & Belt drive \\
\hline 5. & Belt drive \\
\hline 6. & Blower bearing \\
\hline 7. & Blower \\
\hline 8. & Frame \\
\hline 9. & Motor \\
\hline 10. & Barel \\
\hline 11. & Spring \\
\hline 12. & Screw nut \\
\hline 13. & Handle \\
\hline 14. & Discharge rice tray \\
\hline 15. & Discharge tray \\
\hline 16. & Rice sleve \\
\hline 17. & Shaft \\
\hline 18. & Flexible tube \\
\hline
\end{tabular}

\section{CONCLUSION}

This study included study of different research on mini rice milling machine. By this study we were able to make feasible design for a mini rice milling machine which comprises of two steps of rice/ paddy processing first was a chamber of lather roller for husk removal and second step was a rice whitening chamber with help of helix shaft rotating inside a milling sheet. The results revealed that the optimum parameters were: size of hopper feed at $12 \mathrm{~cm} 2$, gap adjuster at $5 \mathrm{~mm}$, and outlet regulator at $5 \mathrm{~cm}$. The limitation of this study was in the cleanup of milling sheet that could affect milling performance leading to the bias in the experiment. Hence the design was found to be safe.
[1]. Purusottam Nayak, Problem and Prospects of Rice Mill Modernization a Case Study, Journal of Assam University 2013

[2]. Nithin C S1, P V Gopinathan2, Modernization of an Existing Rice Mill, International Research Journal of Engineering and Technology 2017

[3]. Jun Fu, Zhi Chen, Lujia Han, Luquan Ren Review Of Grain Threshing Theory And Technology, Int J Agric \& Biol Eng 2018

[4]. Olufemi Bamidele Busari, Olayide Rasaq Adetunji, Peter Olaitan Aiyedun And Sunday Gbenga Aderibigbem, Development Of A Low Cost Rice Milling Machine, Lautech Journal Of Engineering And Technology 10 (2) 2016

[5]. Brian Kristoffer, M. Caringal, Zyrom, S. Dela Rosa, Kyle Vergel, R. Maan, Nestor C. Camello, Design and Development of Rice Milling and Grinding Machine, International Journal Of Science And Engineering 2016

[6]. R. M. Bisen, R. B. Ramawat, Prof. P. B. Khope, Prof. Bp Choudhary, Design, Development And Performance Evaluations Of Mini Rice Mill For Domestic Purpose, International Journal Of Engineering Research \& Technology 2014

[7]. Poonam Dhankhar, Rice Milling, IOSR Journal of Engineering (IOSRJEN), 2014

[8]. Er. B.Kailashkumar Study of Different Kinds of Threshers \& Factors Influencing Threshing Of Crops: A Review, International Journal For Scientific Research \& Development 2019

[9]. Kowshik Kumar Saha, Muhammad Shahinur Alam, A Study On Existing Rice Processing System And Drier Performance In Selected Auto Rice Mills, Resaerchgate,2007

\section{Cite this article as :}

Atif Jamal, "A Literature Review on Design of Mini Rice Milling Machine ", International Journal of Scientific Research in Science and Technology (IJSRST), Online ISSN : 2395-602X, Print ISSN : 2395-6011, Volume 8 Issue 4, pp. 01-04, July-August 2021. Available at doi : https://doi.org/10.32628/IJSRST2183212 Journal URL : https://ijsrst.com/IJSRST2183212 